\title{
ヒト樹状細胞（DC1 とDC2）
}

\author{
門脇 則光
}

要旨

樹状細胞 (dendritic cells；DC) は，最も強力な抗原提示細胞として抗原特異的な免疫反応を開始す る免疫系の中心的な細胞である。ヒトのDCは, 骨髄系のDCであるCD $11 \mathrm{c}^{+} \mathrm{DC}$ 単球由来のDC, および リンパ系のDCと考えられている形質細胞様DC (plasmacytoid DC)という異なるサブセットからなる。 これら異なるDCサブセットは，前駆細胞の段階で異なる菌体成分を認識し，異なるサイトカインを産 生することにより，自然免疫反応に括いて役割分担を果たす。一方，いずれのDCサブセットも，種々 のサイトカインや菌体成分に反応して，侵入してきた抗原を排除するのに適したタイプの異なる獲得免 疫反応を誘導する能力をもつ。このように，DCは広汎な免疫反応に関わることから，自己免疫疾患， 感染症, 癌などの治療において望ましい免疫反応を誘導するためには，DCの機能を制御することが重 要となろう.

〔日内会誌 $92 ： 2047 \sim 2052,2003$ )

Key words : 樹状細胞, 自然免疫, 獲得免疫

\section{1. 樹状細胞とは}

免疫系は，大きく自然免疫系と獲得免疫系の 2つに分けられる。微生物が侵入すると, 好中球, マクロファージなどからなる自然免疫系が速や かに反応して，細菌を食食したり，炎症性サイ トカインを産生したりすることにより，初期の 感染防御に働く。一方, 獲得免疫系は, 多様な 抗原に特異的に反応する多くのT細胞およびB 細胞タローンからなり, 自然免疫系より遅れて 活性化し，抗原特異的な免疫反心を担う。こう した2つのコンポーネント（自然免疫系と獲得 免疫系）が協調して，はじめて病原微生物が排 除される。

自然免疫反応に引き続いて獲得免疫反応が惹 起されるためには，前者が起こっている間に， 抗原提示細胞 (antigen-presenting cell ; APC)が

かどわきのりみつ：京都大学咀液・腫愃内科
抗原を取り込み，消化して，抗原由来のペプチ ドを主要組織適合抗原複合体 (major histocompatibility complex; MHC) 分子上に提示し, T 細胞を活性化する必要がある。

APCには, マクロファージ, B細胞, そして樹 状細胞 (dendritic cell；DC)の 3 種類があるが, この中で, DCだけが, まだ抗原に出会っていな いナイーブなT細胞を強力に活性化する能力をも つ、したがって、DCは自然免疫系と獲得免疫系 の橋渡し役として, 基本的にあらゆる種類の抗 原特異的な免疫反応を開始する, 免疫系の中心 的な細胞といえる1”.

生体から大量のDCを単離することが困難なた めDCの研究は長い間進まなかったが, 骨䯣の造 血前駆細胞や末梢血 $の$ 単球から, DCを比較的大 量に誘導する方法が開発されるにつれて，DC の分化経路や機能が急速に明らかにされつつあ る.また, 種々の炎症性疾患の病態解明や癌免 疫療法への用という臨床的な観点からも, DC は大きな注目を集めている2。 


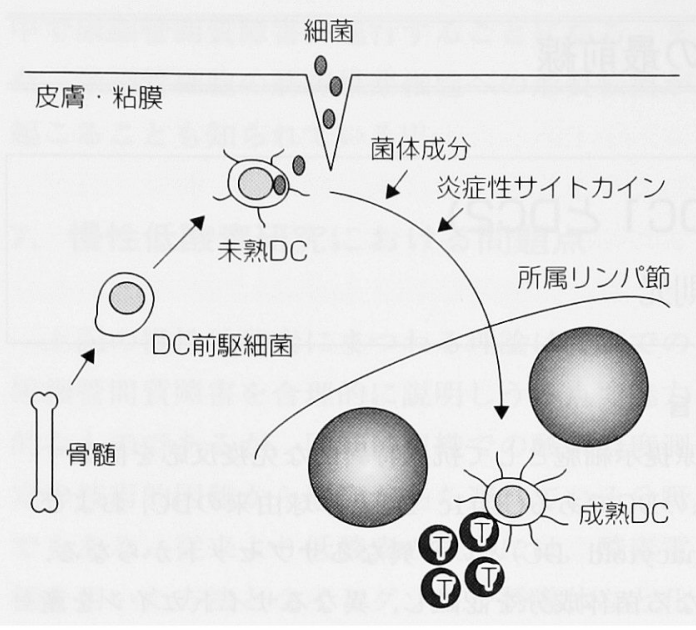

図 1.DCのライフサイクル

骨随で作られたDC前駆細胞は，皮膚や粘膜などの 末梢組織に移動し末熟DCとして分布する.末熟DC は抗原(図では細菌)を取り込んだあと菌体成分や 炎症性サイトカインの刺激を受けて活性化し成熟 DCになる. それとともに，DCはリンパ管に入り 所属リンパ節の丁細胞領域に移動して,貪食した抗 原に特異的なT細胞を刺激することにより，獲得免 疫反応を誘導する.そのあとDCはアポトーシスで 死滅する場合と,死滅しないがIL-12 の産生を停止 する場合があると報告されている.

DCは,その名の由来である樹状突起 (dendrite) をもつという形態的特徵を共有するが, 単一の 細胞ではなく, 細胞起源や機能の異なるサブセッ 卜からなる ${ }^{3}$. そして, 抗原特異的な獲得免疫反 応の質を決定づける「Th1，Th2」という異なる ヘルパーT ( T helper ; Th) 細胞の分化が, 異な るDCサブセットによって誘導されるのではない かという仮説から、これらのTh細胞を誘導する $\mathrm{DC}$ サブセットが「DC1，DC2」と当初命名され ていた. 本稿ではこうしたヒト DCサブセットの 機能的差異を中心に, DCとヒト疾患の関わりを 紹介する。

\section{2. 樹状細胞の一生}

骨髄で作られたDCの前駆細胞は, 顆粒球・マ クロファージコロニー刺激因子（granulocyte- macrophage colony-stimulating factor ; GM$\mathrm{CSF}$ ）な゙の造血系サイトカインによってDC に分化し，皮膚や粘膜といった病原微生物の侵 入門戸に広く分布する”（図 1)。この段階のDC は「未熟 DC」とよばれ，T細胞を刺激する能力 は弱い代わりに，抗原をさかんに貪食し消化す る能力をもっている. 微生物が侵入すると, 未 熟DCはそれを貪食して, 菌体成分, 炎症性サイト カイン, CD40 リガンド (CD40 ligand ; CD40L) などの刺激を受けて活性化し「成熟DC」になる とともに、リンパ管に入って所属リンパ節のT 細胞領域に移動する (図 1)。その過程で成熟DC は抗原を領食する能力を失う代わりに，抗原由 来のペプチドを $\mathrm{MHC}$ 分子上に提示し,それを $\mathrm{CD}$ $80, \mathrm{CD} 86$ といった共刺激分子とともに高発現す ることにより，T細胞を強力に活性化する能力を 獲得する.このようにDCは, 骨髄から末梢組織 へ，そしてリンパ組織へとダイナミックに移動 して抗原を感染巣からリンパ組織へ運び，それ をT細胞に提示することによって抗原特異的な免 疫反応を惹起する重要な働きを担っている（図 1).

\section{3.ヒトDCサブセットの細胞起源}

ヒトのDCを研究する場合, 入手しやすいこと から多くの場合末梢血が用いられる．末梢血に は, lineage marker (lin) ${ }^{-} \mathrm{CD} 11 \mathrm{c}^{+} \mathrm{CD} 4{ }^{+}$の未熟DC と, $\operatorname{lin}^{-} \mathrm{CD} 11 \mathrm{c}^{-} \mathrm{CD} 4^{+}$の形質細胞椂の形態をした DC前駆細胞 (plasmacytoid pre-DC) という，形 態および表面マーカーの面から大きく異なる 2 つのDCサブセットがある゙）（図 $2 \mathrm{~A}$ )。また，単 球をGM-CSFとインターロイキン (interleukin ; IL) -4 の存在下で数日間培養するとDCに分化す る1).これらのDCサブセットのうち, CD11c ${ }^{+}$の DCは, 骨髄系マーカーを発現することなどから 骨髄系DCであり, 単球由来のDCと少なくとも類 縁関係にある。一方, plasmacytoid pre-DCは, 発現分子のパターンなどから, リンパ球と起源 
A

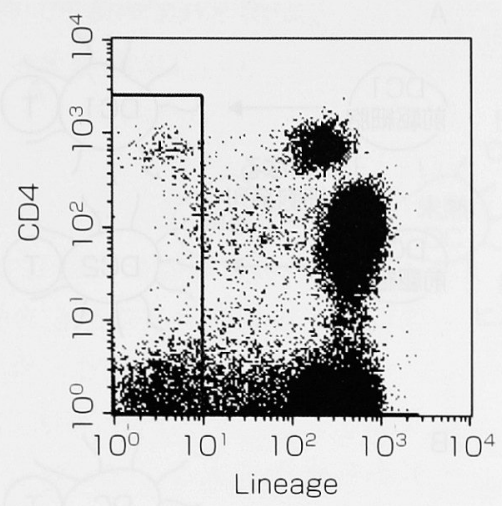

$B$

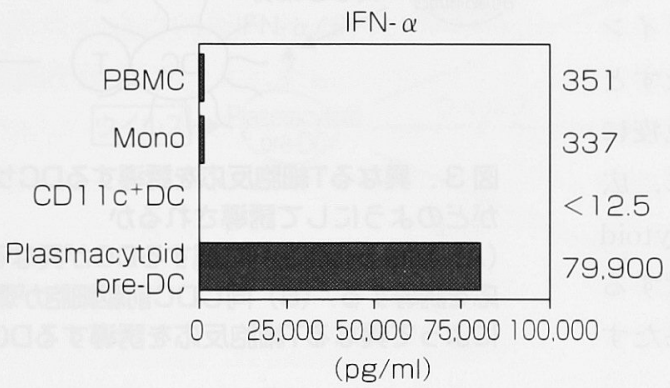

図 2 .ヒト末梢血中のDCサブセットと, それらのIFN- $\alpha / \beta$ 産生能

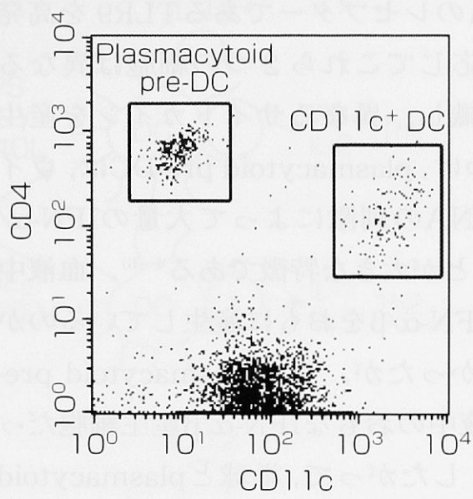

IFN- $\beta$

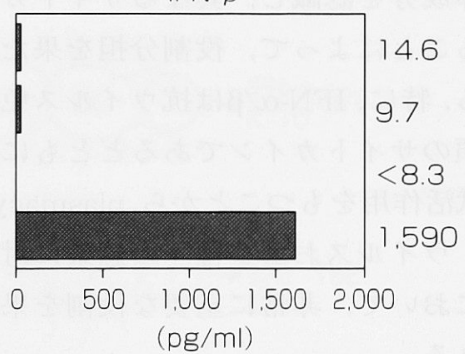

（A）フローサイトメトリーによる末梢血plasmacytoid pre-DCとCD $11 c^{+} D C の$ 同定. 末梢 血単核球 (peripheral blood mononuclear cells ; PBMC) をlineage marker (CD3, CD 14, CD19, CD34, CD56), CD4, CD11cで三重染色し, lin-細胞をCD4 とCD1 1c で展開すると, lin-CD4 ${ }^{+}$CD $11 c^{-}$- $p$ plasmacytoid pre-DCとlin-CD4low $C D 11 c^{\text {high }}$ のCD $11 \mathrm{C}+D C$ が同定できる. いずれもPBMCの0.1〜0.5\%とまれな細胞である.

(B) 全PBMC, 単球, CD $11 \mathrm{C}^{+} \mathrm{DC}$, plasmacytoid pre-DCのIFN- $\alpha / \beta$ 産生能. 各細胞分画を $\gamma$ 照射で弱毒化した単純ヘルペスウイルスの存在下で 24 時間培養すると, plasmacytoid preDCはきわめて大量のIFN- $\alpha / \beta$ （特にIFN- $\alpha ）$ を産生する.

を同じくするDCと考えられているが3)，直接的 な証拠に基づいていないことから, 確定はして いない.

4. DCサブセットの自然免疫反応における 役割分担

単球とplasmacytoid pre-DCという血液中の 2 つのDC前駆細胞は, 多くの点で相違点をもつ全 く異なる細胞である.特に，(1) Toll-like recep-
tor（TLR）と呼ばれる，種々の菌体成分を認識 するレセプターの発現パターンが全く異なるこ とせ，（2） plasmacytoid pre-DCがきわめて大量 のインターフェロン (interferon ; IFN)- $\alpha / \beta$ を産 生すること ${ }^{4 \sim 6}$ （図 2B）は注目に值する. 単球は, グラム陽性球菌のペプチドグリカンなどのレセ プターであるTLR2や,グラム陰性桿菌のリポ多 糖 (lipopolysaccharides ; LPS) のレセプターで あるTLR4 などを高発現する一方, plasmacytoid pre-DCは, TLR7や, 種々の細菌がもつ非メチ 
ル化CpG DNAのレセプターであるTLR9 を高発 現し，それに応じてこれら2つの細胞は異なる 菌体成分を認識し，買なるサイトカインを産生 する゙ .とりわけ, plasmacytoid pre-DCは,ウイ ルスやCpG DNAの刺激によって大量のIFN- $\alpha$

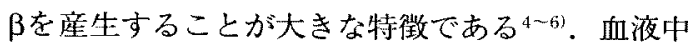
のどの細胞がIFN- $\alpha / \beta$ を㧍もに産生しているのか わかっていなかったが,このplasmacytoid preDCが,ヒト血液中のおもなIFN- $\alpha / \beta$ 産生細胞だっ たわけである。したがって, 単球とplasmacytoid pre-DCという $2 つ の$ 細胞は, DC前駆細胞である だけでなく,感染初期の自然免疫反応に扔いて， 異なる菌体成分を認識し，異なるサイトカイン を産生することによって，役割分担を果たすと 考えられる。特に, IFN- $\alpha$ 仙抗ウイルス免疫に おいて必須のサイトカインであるとともに，広 汎な免疫賦活作用をもつことから, plasmacytoid pre-DCは，ウイルスおよび種々の感染に対する 生体防御において，非常に重要な役割を果たす と考えられる。

5.DCサブセットによって誘導される異な るへルパーT細胞反応

このような自然免疫反応に引き続いて起こる 抗原特異的な獲得免疫反応の質的な違いは, $\mathrm{CD}^{+}$Th細胞がどのようなサイトカインを産生す るかによって大きく決定づけられる。たとえば， IFN- $\gamma$ PIL-2 などを産生するTh1 細胞は,マクロ ファージやCD8+細胞障害性T細胞を刺激するこ とによって招もに細胞性免疫を誘導し，結核菌 やウイルスのような細胞内微生物の排除に働く のに対し,IL-4，IL-5，IL-10などを産生するTh2 細胞は, B細胞や好酸球を刺激することによって， 寄生虫のような細胞外微生物の排除に働くとと もに,アレルギー疾患の発症にも関与している. ナイーブCD4+T細胞のこういった異なる Th細胞 への分化がどういう要因によって決定づけられ るかは, 自己免疫疾患, アレルギ一, 移植免疫,
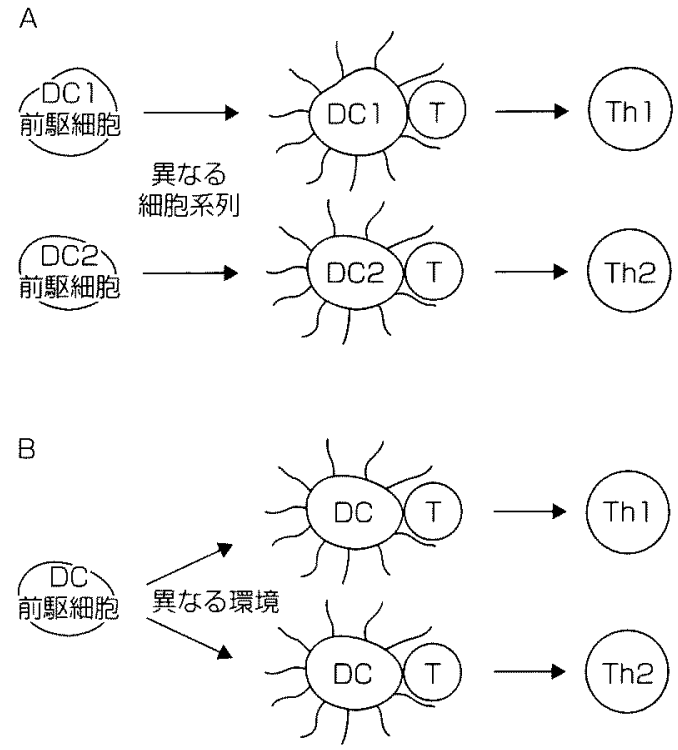

図 3、異なるT細胞反応を誘導するDCサブセット がどのようにして誘導されるか

（A）異なる細胞系列に属するDCが異なるT細胞反 応を誘導する. (B) 同じDC前駆細胞か環境の遥い によって異なるT細胞反応を誘導するDCになる。

腫瘍免疫など広範な免疫学的病態を理解し，こ れらの疾患の新たな治療法を開発するうえでき わめて重要な問題である.

ナイーブT細胞が最初に抗原と出会って活性化 する際に働く最も強力なAPCはDCであることか ら，どのようなDCがT細胞を刺激するかがTh 細胞の分化の方向性を決定づけるうえで重要な 役割在果たすと考えられる。DCによって多様な Th反応が誘導されるメカニズムとして，異なる DC前駆紐胞が異なるTh反応を誘導するDCに分 化するモデル（図 3A）と，同じDC前駆細胞が 異なる刺激を受けることによって抗原の種類に 応じたTh反応を誘導するDCに分化するモデル (図 3B) が考えられる.当初われわれのグループ はAのモデルを想定し,CD40Lの刺激を受けて成 熟した単球由来の骨野道系DCがLL-12を産生するこ とによりTh1 反応を誘導するのに対し, plasmacytoid pre-DCをIL-3 の存在下で培養して得られ るDCはTh2 反応を誘導することを見出しだ 


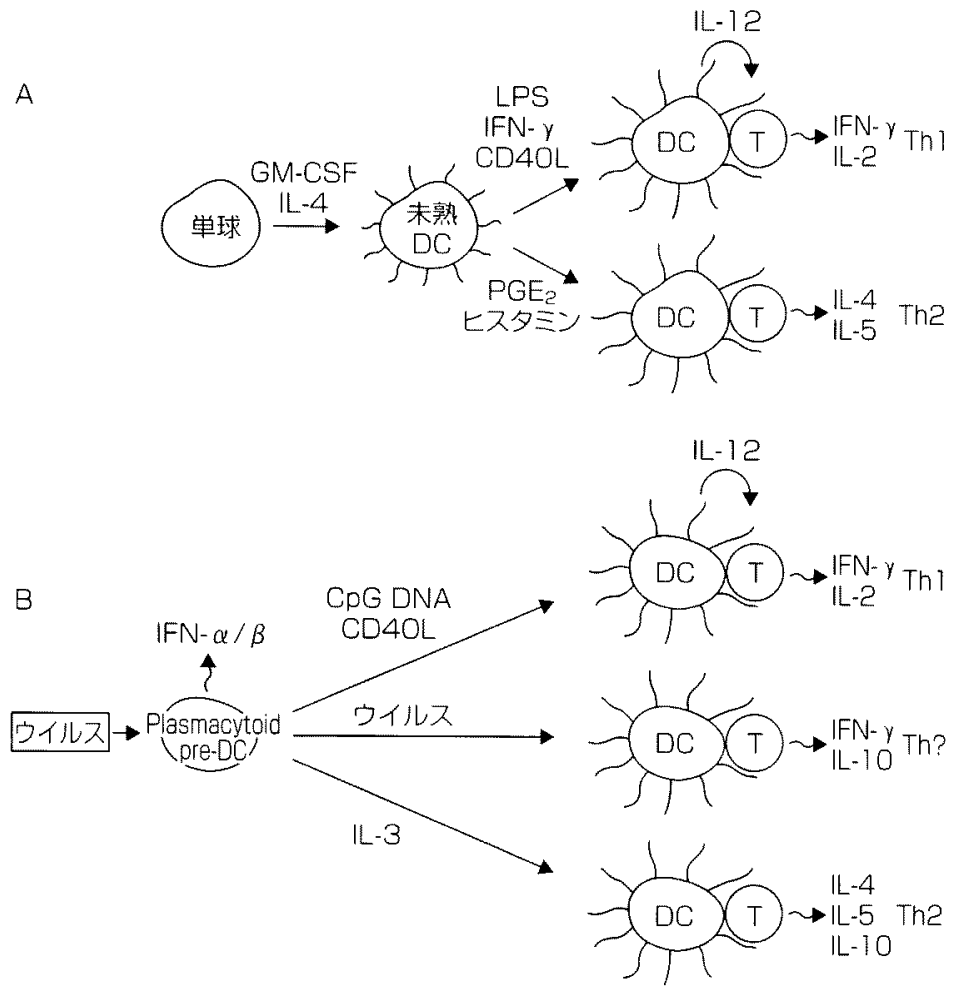

図 4. 異なるDCサブセットによる異なるTh反応の誘導メカニズム

(A) GM-CSFとIL-4 により単球から分化した未熟なDCが細菌、IFN- $\gamma$ またはCD4OLの刺激を 受けると、IL-12 を産生しTh1 反応を誘導するDCに成熟するのに対し，PGE 刺激を受けると, IL-12は産生せずTh2反応を誘導するDCに成熟する.

(B) plasmacytoid pre-DCはウイルス刺激により大量のIFN- $\alpha / \beta$ 産生した後DCに分化し， CD4 ${ }^{+}$T細胞によるIFN- $\gamma$ とIL-10の産生を誘導する. また，非メチル化CpG DNAとCD4OL の刺激を受けると，IL-12を産生しTh1 反応を誘導する.さらに, plasmacytoid pre-DC はIL-3によってもDCに分化し，CD4+T細胞によるTh2サイトカインの産生を誘導する.

(図 4).この知見に基づいて, 単球由来のDC をDC1, plasmacytoid pre-DC由来のDCをDC2 と名づけた.

しかし，その後の研究により，単球由来のDC

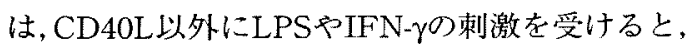
IL-12 産生しTh1 反応を誘導するのに対し,プ ロスタグランジン (prostaglandin ; PG) $\mathrm{E}_{2}$ やヒ スタミンといったIL-12 の産生を抑制するような 因子の刺激を受けると，Th2 反応を誘導するよ うになる8 (図 4A).一力, plasmacytoid preDCは，CpG DNAとCD40Lの刺激を受けると， IL-12を産生しTh1 反応を誘導し9', ウイルス刺
激を受けるとIFN- $\alpha / \beta$ 産生するとともにDC

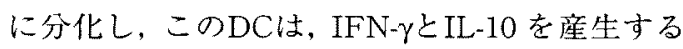
Th1 ともTh2 ともいえないTh細胞を誘導するこ とがわかっだ（図 4B）。

このように，そ㞦ぞれのDCサブセットは，周 囲の細胞から発せられるシグナルや微生物由来 の成分を感知して，侵入してきた抗原を排除す るのに適したタイプの異なる免疫反応を誘導す る柔軟性をもつと考えられる。すなわ当図 3 A ではなくむしろBのモデルが正しいといえる。 の際, IL-12 が誘導されればTh1, 誘尊されなけ ればTh2 反応が起こるという具合に, DCが, 強 
力なThl 誘導サイトカインであるIL-12を産生す るか否かがTh1，Th2 老決める重要な鍵を握って いる、以上より，「DCl， DC2」という名称は， あたかも Th1，Th2 反応のみを誘導するDCサブ 七ットが存在するかのような印象を与え，寒態 に即していないと考えられることから，濫用し ないのが適切であろう。

\section{6. 疾患の病態におけるDC}

DCは基本的にあらゆる抗原特異的な免疫反応 を惹起する細胞であることから, 種々の免疫性, 炎症性疾患の病態形成に関与していると考えら れる。たとえば, Sjögren症候群の患者末梢血中 のCD11c 骨髄系DCが減少し病巣に浸潤してい ることが示されている。 一方 plasmacytoid preDCは, 壊死性リンパ節炎(菊池病), 結核やサル コイドーシスによる肉芽腫性リンパ節炎などの リンパ節病変に集まっており，また皮㖇のルー プス病変でIFN- $\alpha$ を産生し,ループスの病態形成 に重要な役割を果たしている。さらに, plasmacytoid pre-DCはアレルゲンに暴露された鼻粘膜 にも集まっていることから、このような場合は Th2 誘導性のDCに分化し、アレルギー疾患の発 症に関与しているのかもしれない。さらに，日 和見感染に罹患しやすいHIV 感染患者では, 血中 のplasmacytoid pre-DCが著明に減少しているこ とからこの細胞が, 特にIFN- $\alpha / \beta$ を大量に産生 することによって, 生体防御において重要な役 割を果たすことが示唆される.

\section{おわりに}

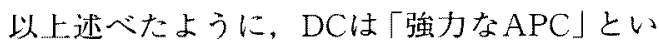
う基本機能を共通項として持つとともに，抗原 の種類に応じて多様なタイプのT細胞反応を誘導 する。それだけでなく，本稿では触れなかった が，未熟な，あるいは十分成熟していない段階 では免疫抑制的に働き，免疫寛容の維持にも関
与することが示されている(10). 免疫系のかなめの 細胞としてこうした広沉な免疫反応を制御する DCネットワークの乱れは, 自己免疫疾患, 感染 症など種々の炎症性疾患の発症や病態形成に深 く関与していると考えられる。また,強力なAPC」 というDCの基本機能を利用して, 癌に対する強 い免疫反応を誘導することもできる゙．したがっ て, 自己免疫疾患, 感染症, 癌などの治療にお いて望ましい免疫反応を誘導するためには, DC の機能を操作することが重要となろう. 今後ポ ストゲノム時代の幕開けとともにDCのさまざま な機能分子が同定されれば，そういった分子が 創薬や遺伝子治療の標的となると考えられる. 基礎, 臨床の両面から、DCの研究動向は目が離 せないものとなるだろう。

\section{文献}

1) Banchereau J, et al: Immunobiology of dendritic cells. Annu Rev Immunol 18: 767-811, 2000.

2) Fong L, Engleman EG : Dendritic cells in cancer immunotherapy. Annu Rev Immunol 18:245-273, 2000.

3) Liu YJ, et al: Dendritic cell lineage, plasticity and crossregulation. Nat Immunol 2: 585-589, 2001.

4) Kadowaki N, et al : Subsets of Human Dendritic Cell Precursors Express Different Toll-like Receptors and Respond to Different Microbial Antigens. J Exp Med 194 : 863-870, 2001.

5) Siegal FP, et al: The nature of the principal type 1 interferon-producing cells in human blood. Science 284 : 1835-1837. 1999.

6) Kadowaki $\mathrm{N}$, et al: Natural interferon alpha/betaproducing cells link innate and adaptive immunity. J Exp Med 192: 219-226, 2000.

7) Rissoan M-C. et al: Reciprocal control of $T$ helper cell and dendritic cell differentiation. Science 283:1 183-1186. 1999.

8) Kalinski $P$, et al : T-cell priming by type-1 and type- 2 polarized dendritic cells : the concept of a third signal. Immunol Today 20 : 561-567, 1999.

9) Krug A et al : Toll-like receptor expression reveals $\mathrm{CpG}$ DNA as a unique microbial stimulus for plasmacytoid dendritic cells which synergizes with CD40 ligand to induce high amounts of IL-12. Eur J Immunol 31:3026-3037, 2001.

10) Lutz MB, Schuler G:Immature, semi-mature and fully mature dendritic cells : which signals induce tolerance or immunity? Trends Immunol 23 : 445-449, 2002. 